\title{
THE RENAL RESPONSE TO CHRONIC RESPIRATORY ACIDOSIS ${ }^{1}$
}

\author{
By W. JAMES SULLIVAN ${ }^{2}$ AND PHILIP J. DORMAN 2 WITH THE TECHNICAL ASSISTANCE \\ oF MARTHA BARRETT MACLEOD AND MARY ELLEN PARKS
}

(From the Department of Physiology, Cornell University Medical College, New York, N. Y.)

(Submitted for publication August 23, 1954; accepted October 27, 1954)

An increase in the carbon dioxide tension of the body fluids is accompanied by an increase in the concentration of bicarbonate bound base, a fact which minimizes the change in $\mathrm{pH}$ that would otherwise ensue $(1,2)$.

$A$ priori, it is evident that an elevated plasma bicarbonate concentration can be maintained only by enhancement of the rate of renal tubular reabsorption of bicarbonate. That such enhancement occurs in response to acute respiratory acidosis has been established by experiments performed in our laboratory as well as in other laboratories (3-5). It has also been shown that the elevated $\mathrm{pCO}_{2}$, and not the change in $\mathrm{pH}$, is the stimulus responsible for enhancing this tubular activity. However, the data reported in these experiments on dogs indicate that the magnitude of the enhancement of tubular reabsorption of bicarbonate produced by acute respiratory acidosis is not sufficient to account for the elevated plasma concentrations frequently observed in states of chronic carbon dioxide retention in man. This suggests the possibility that some variety of tubular adaptation occurs in chronic respiratory acidosis which requires time for its development and which therefore is not seen in acute conditions.

\section{METHODS}

A total of 30 experiments was performed on eight mongrel female dogs. For each dog data on bicarbonate reabsorption at normal $\mathrm{pCO}_{2}$ and during acute respiratory acidosis were obtained prior to the start of chronic experiments. The animals were maintained in metal screened metabolism cages covered by plastic hoods. Compressed air and $\mathrm{CO}_{2}$ flowed into the cages at rates sufficient to insure adequate oxygenation. The relative flow rates of the two gasses were adjusted so as to maintain a $\mathrm{CO}_{2}$ concentration of 10 to 14 per cent within the cages. This $\mathrm{CO}_{2}$ concentration was determined pe-

1 Supported by a grant from the Life Insurance Medical Research Fund.

2 Fellow of the Life Insurance Medical Research Fund. riodically using a Cambridge hot-wire analyzer. Cages were opened for 5 to 10 minutes each day for feeding and cleaning.

Prior to the clearance periods, the dog was removed from the cage and anesthetized with sodium pentobarbital in doses not exceeding $30 \mathrm{mg}$. per $\mathrm{Kg}$. An endotracheal airway was inserted and connected, via a Digby-Leigh non-rebreathing valve, to a Douglas bag containing 12 per cent $\mathrm{CO}_{2}$ and 88 per cent $\mathrm{O}_{2}$ which was breathed throughout the clearance periods. In most of the experiments the dog breathed spontaneously throughout. In a few experiments spontaneous respirations were abolished with a curarizing agent and ventilation was maintained by a high capacity respiration pump. ${ }^{3}$ Details of the analytical methods and calculations have been given in a previous publication from this laboratory (3).

\section{RESULTS}

The effect of chronic respiratory acidosis on the renal tubular reabsorption of bicarbonate bound base was determined in twenty-four experiments. Duration of acidosis in these experiments varied from 12 hours to 77 days. Data from two such experiments are presented in Table I. In these experiments, creatinine and mannitol in an approximately isotonic solution were infused during the first two periods. In the subsequent periods, plasma bicarbonate was progressively elevated by suitable priming doses and sustaining infusions of sodium bicarbonate.

Experiment No. C-1 in Table I illustrates the effect of fifteen days of chronic respiratory acidosis on the renal reabsorption of bicarbonate.

During the first two periods, prior to the infusions of bicarbonate, the plasma bicarbonate concentration was supranormal. As illustrated in the last two columns of this table, renal reabsorption of bicarbonate was also elevated significantly. Reabsorption was essentially complete; excretion was virtually nil. With the infusion of sodium bicarbonate, plasma bicarbonate concentration rose

${ }^{3}$ Constructed in the apparatus shop of the Department of Physiology by Mr. Raymond E. Phipps. 
TABLE I

Experiments illustrating the effect of chronic respiratory acidosis on the renal tubular reabsorption of bicarbonate bound base

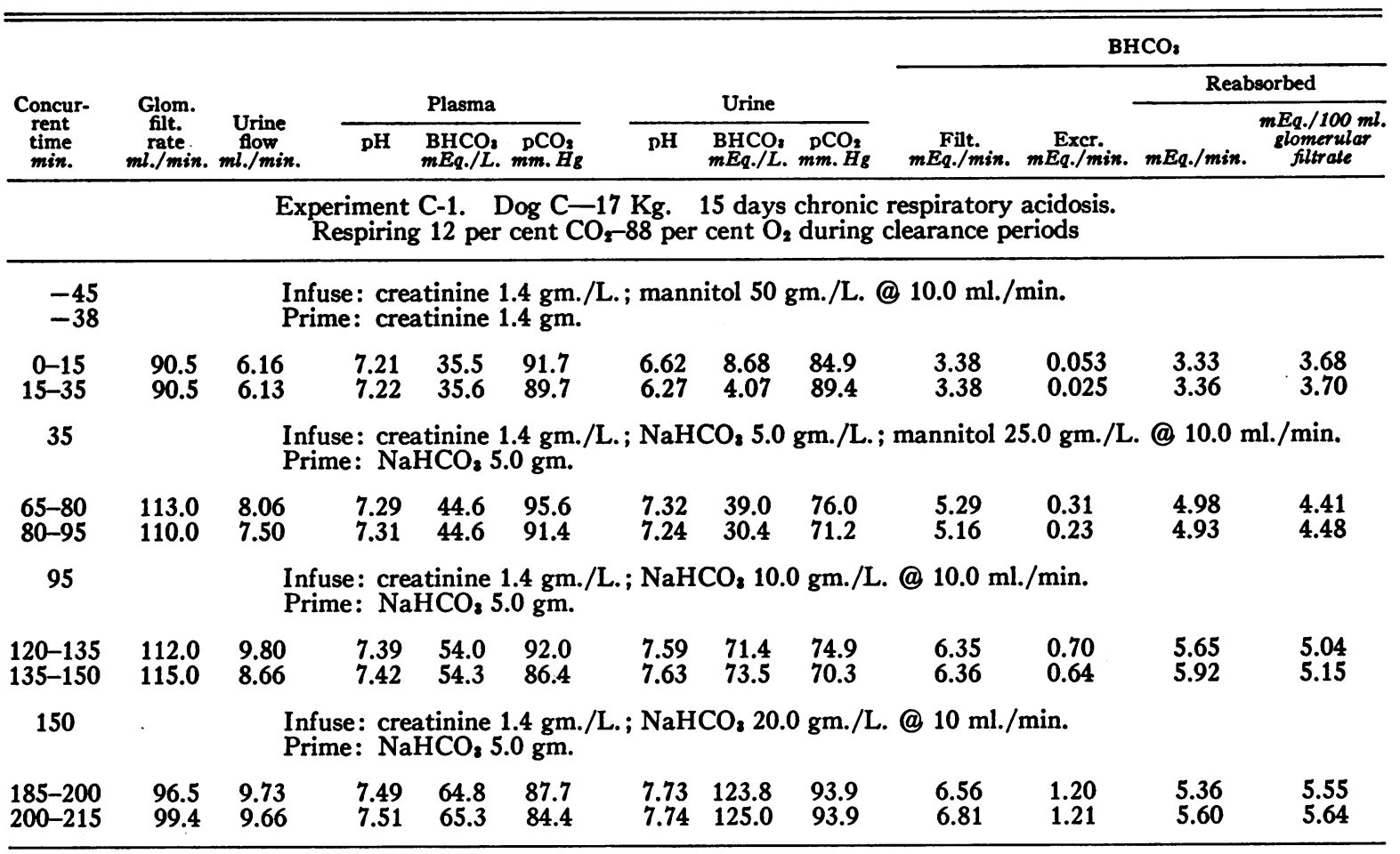

Experiment C-7. Dog $\mathrm{N}-16.5 \mathrm{Kg} .46$ hours chronic respiratory acidosis

\begin{tabular}{|c|c|c|c|c|c|c|c|c|c|c|c|c|}
\hline $\begin{array}{l}-75 \\
-70\end{array}$ & \multicolumn{12}{|c|}{$\begin{array}{l}\text { Infuse: creatinine } 1.0 \mathrm{gm} . / \mathrm{L} . ; \text { mannitol } 50.0 \mathrm{gm} . / \mathrm{L} . \text { @ } 10.0 \mathrm{ml} . / \mathrm{min} \text {. } \\
\text { Prime: creatinine } 1.3 \mathrm{gm} .\end{array}$} \\
\hline $\begin{array}{r}0-15 \\
15-30\end{array}$ & $\begin{array}{l}40.5 \\
38.0\end{array}$ & $\begin{array}{l}5.17 \\
5.77\end{array}$ & $\begin{array}{l}7.21 \\
7.19\end{array}$ & $\begin{array}{l}31.3 \\
31.8\end{array}$ & $\begin{array}{l}80.8 \\
86.0\end{array}$ & $\begin{array}{l}6.15 \\
6.13\end{array}$ & $\begin{array}{l}2.38 \\
2.52\end{array}$ & $\begin{array}{l}68.9 \\
75.0\end{array}$ & $\begin{array}{l}1.33 \\
1.27\end{array}$ & $\begin{array}{l}0.01 \\
0.01\end{array}$ & $\begin{array}{l}1.32 \\
1.26\end{array}$ & $\begin{array}{l}3.26 \\
3.32\end{array}$ \\
\hline 30 & & \multicolumn{11}{|c|}{$\begin{array}{l}\text { Infuse: creatinine } 1.0 \mathrm{gm} . / \mathrm{L} . ; \mathrm{NaHCO}_{2} 6.0 \mathrm{gm} . / \mathrm{L} . ; \text { mannitol } 25.0 \mathrm{gm} . / \mathrm{L} . \text { @ } 10.0 \mathrm{ml} . / \mathrm{min} \text {. } \\
\text { Prime: } \mathrm{NaHCO}_{3} 4.0 \mathrm{gm} \text {. }\end{array}$} \\
\hline $\begin{array}{l}60-75 \\
75-90\end{array}$ & $\begin{array}{l}40.7 \\
40.9\end{array}$ & $\begin{array}{l}6.27 \\
6.63\end{array}$ & $\begin{array}{l}7.26 \\
7.28\end{array}$ & $\begin{array}{l}37.5 \\
37.2\end{array}$ & $\begin{array}{l}86.4 \\
81.4\end{array}$ & $\begin{array}{l}6.67 \\
6.66\end{array}$ & $\begin{array}{l}7.19 \\
6.71\end{array}$ & $\begin{array}{l}62.4 \\
59.8\end{array}$ & $\begin{array}{l}1.60 \\
1.60\end{array}$ & $\begin{array}{l}0.04 \\
0.04\end{array}$ & $\begin{array}{l}1.56 \\
1.56\end{array}$ & $\begin{array}{l}3.82 \\
3.80\end{array}$ \\
\hline 90 & \multicolumn{12}{|c|}{$\begin{array}{l}\text { Infuse: creatinine } 1.0 \mathrm{gm} . / \mathrm{L} . ; \mathrm{NaHCO}_{3} 12.0 \mathrm{gm} . / \mathrm{L} . @ 10.0 \mathrm{ml} . / \mathrm{min} . \\
\text { Prime: } \mathrm{NaHCO}_{3} 4.5 \mathrm{gm} .\end{array}$} \\
\hline $\begin{array}{l}120-135 \\
135-150\end{array}$ & $\begin{array}{l}42.0 \\
43.5\end{array}$ & $\begin{array}{l}5.80 \\
5.71\end{array}$ & $\begin{array}{l}7.40 \\
7.41\end{array}$ & $\begin{array}{l}49.1 \\
51.9\end{array}$ & $\begin{array}{l}81.7 \\
84.4\end{array}$ & $\begin{array}{l}7.53 \\
7.60\end{array}$ & $\begin{array}{l}45.3 \\
58.9\end{array}$ & $\begin{array}{l}54.4 \\
60.2\end{array}$ & $\begin{array}{l}2.16 \\
2.37\end{array}$ & $\begin{array}{l}0.26 \\
0.34\end{array}$ & $\begin{array}{l}1.90 \\
2.03\end{array}$ & $\begin{array}{l}4.53 \\
4.67\end{array}$ \\
\hline 150 & \multicolumn{12}{|c|}{$\begin{array}{l}\text { Infuse: creatinine } 1.0 \mathrm{gm} . / \mathrm{L} . ; \mathrm{NaHCO}_{2} 18.0 \mathrm{gm} . / \mathrm{L} . \text { @ } 10.0 \mathrm{ml} . / \mathrm{min} \text {. } \\
\text { Prime: } \mathrm{NaHCO}_{2} 4.5 \mathrm{gm} .\end{array}$} \\
\hline $\begin{array}{l}180-195 \\
195-210\end{array}$ & $\begin{array}{l}47.5 \\
47.7\end{array}$ & $\begin{array}{l}7.60 \\
7.93\end{array}$ & $\begin{array}{l}7.46 \\
7.47\end{array}$ & $\begin{array}{l}60.8 \\
64.2\end{array}$ & $\begin{array}{l}88.4 \\
91.0\end{array}$ & $\begin{array}{l}7.74 \\
7.75\end{array}$ & $\begin{array}{l}114.9 \\
130.3\end{array}$ & $\begin{array}{l}84.2 \\
93.8\end{array}$ & $\begin{array}{l}3.04 \\
3.21\end{array}$ & $\begin{array}{l}0.87 \\
1.03\end{array}$ & $\begin{array}{l}2.17 \\
2.18\end{array}$ & $\begin{array}{l}4.57 \\
4.57\end{array}$ \\
\hline
\end{tabular}

progressively to $65 \mathrm{mEq}$. per $\mathrm{L}$. in the last period. Renal tubular reabsorption of bicarbonate also rose to reach a value in the last period of 5.64 $\mathrm{mEq}$. per $100 \mathrm{ml}$. filtrate. In contrast, the average value for the normal dog is $2.5 \mathrm{mEq}$. per $100 \mathrm{ml}$. filtrate, and for the dog in acute respiratory acidosis, with a comparable elevation of carbon diox- ide tension, it is $3.3 \mathrm{mEq}$. per $100 \mathrm{ml}$. filtrate $(3,6)$.

Essentially similar results were obtained after 46 hours of respiratory acidosis, as is shown in experiment No. C-7 in Table I. Here, prior to the infusion of bicarbonate, the renal reabsorption of bicarbonate averaged $3.29 \mathrm{mEq}$. per $100 \mathrm{ml}$. fil- 
trate in the first two periods. With progressive increase in plasma bicarbonate, renal bicarbonate reabsorption rose and became essentially constant during the last four periods, the average value being $4.58 \mathrm{mEq}$. per $100 \mathrm{ml}$. filtrate.

In Figure 1 are presented the data on renal bicarbonate reabsorption, as a function of plasma bicarbonate concentration, obtained in this group of experiments. In this graph the mean values for bicarbonate reabsorption under conditions of normal $\mathrm{pCO}_{2}$ and in acute respiratory acidosis are indicated by the appropriately labeled horizontal lines. It is apparent that in the range of plasma bicarbonate concentration at which frank excretion occurs; i.e., above $40 \mathrm{mEq}$. per liter, the renal reabsorption of bicarbonate in chronic respiratory acidosis is significantly greater than in either control or acute experiments. Inspection of the data of individual experiments reveals considerable splay in the "titration" curve; i.e., saturation of the mechanism of bicarbonate reabsorption is approached gradually over a wide range of plasma bicarbonate concentration. This is in con- trast to observations made when plasma carbon dioxide tension is normal or acutely increased. Under these conditions, a similar "titration" of the tubules by progressive elevation of plasma bicarbonate concentration yields a curve with a relatively sharp angle at that plasma concentration at which saturation of the mechanism occurs.

Data on the renal reabsorption of bicarbonate bound base, as a function of the duration of respiratory acidosis, are presented in Figures 2A and $2 \mathrm{~B}$. In Figure $2 \mathrm{~A}$ are plotted the rates of reabsorption of bicarbonate bound base obtained prior to the infusion of sodium bicarbonate, and in Figure 2B, the maximal rates of reabsorption attained during bicarbonate loading. Although there is considerable scatter in the data, it is apparent that the increase in renal reabsorption in respiratory acidosis occurs relatively rapidly in the first 24 to 48 hours; i.e., from a mean acute value of 3.3 to approximately $4.6 \mathrm{mEq}$. per hundred $\mathrm{ml}$. of filtrate, with a relatively slower increase thereafter. It is also apparent that the capacity of the renal tubular mechanism to reab-

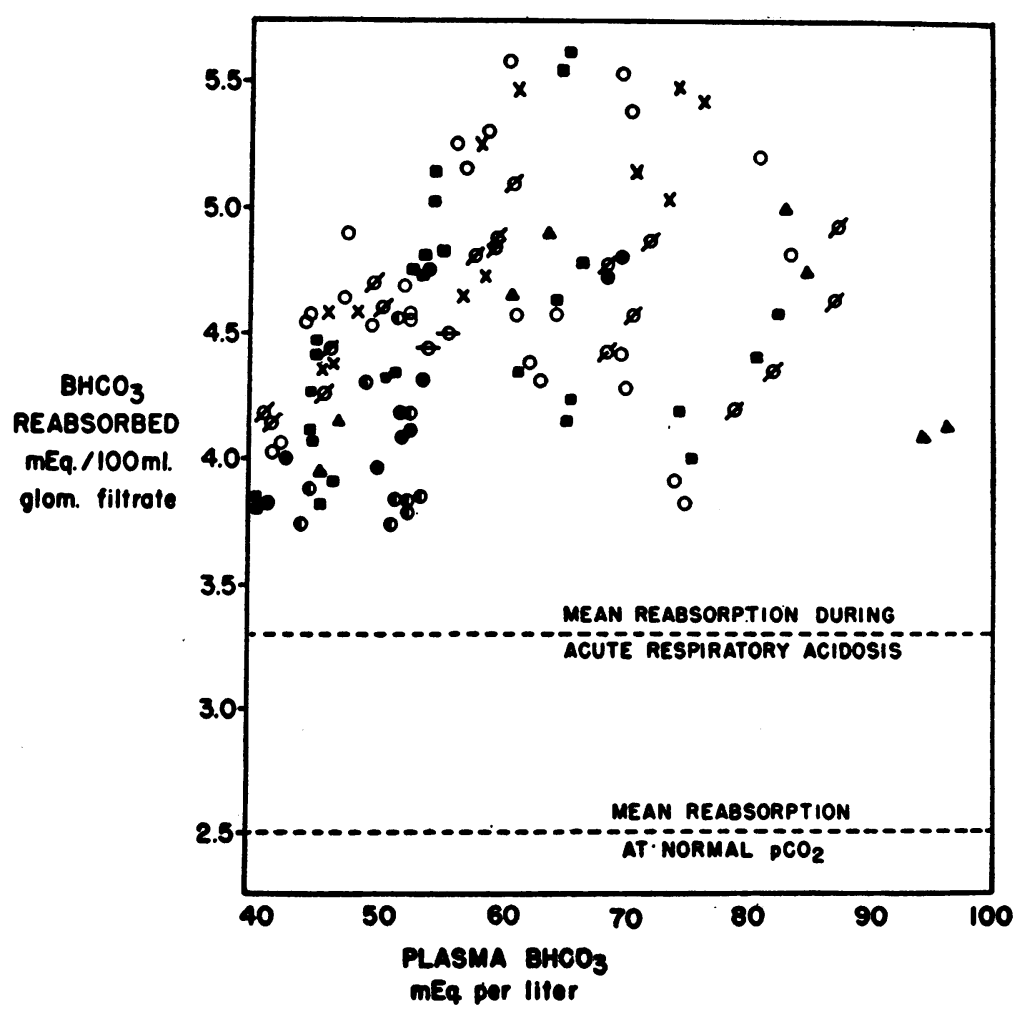

Fig. 1. The Renal Tubular Reabsorption of Bicarbonate as a Function of Plasma Bicarbonate Concentration 

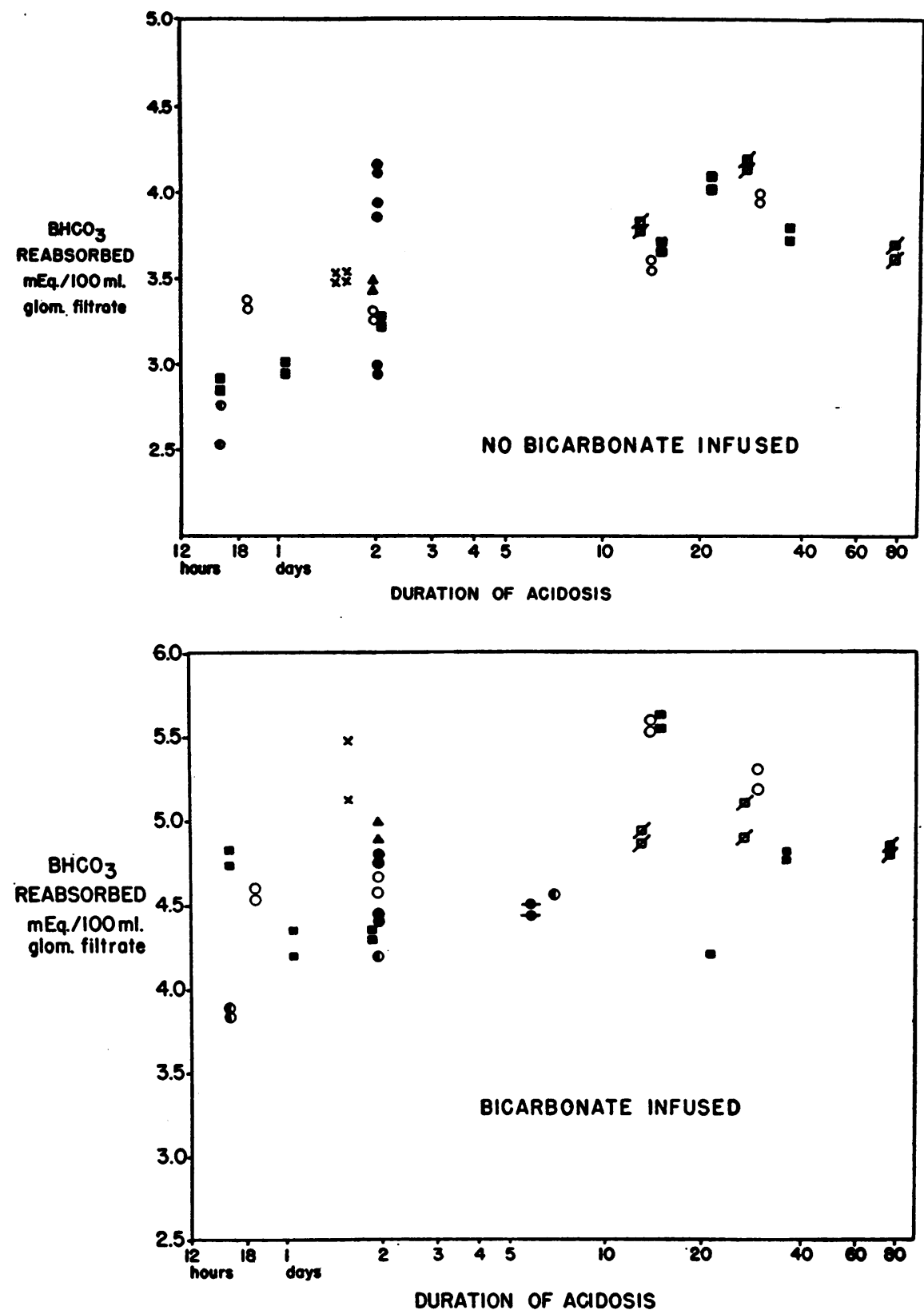

Fig. 2. Renal Tubular Reabsorption of Bicarbonate as a Function of DuraTION of Acidosis

A-Pror to the Infusion of Bicarbonate,

B-During Bicarbonate Loading

sorb bicarbonate, as indicated by the rates attainable during bicarbonate loading (Figure 2B), is significantly greater than would be indicated by the plasma bicarbonate concentration attained during respiratory acidosis, before any bicarbonate is infused (Figure 2A).
Inhibitors of the enzyme carbonic anhydrase, such as the sulfonamide compound No. 6063 , employed clinically under the proprietary name Diamox ${ }^{\$}, 4$ have been shown to depress renal tubular reabsorption of bicarbonate. This depression has

\footnotetext{
Lederle.
} 
TABLE II

Experiment illustrating the effect of No. 6063 on renal tubular reabsorption of bicarbonate bound base in chronic respiratory acidosis

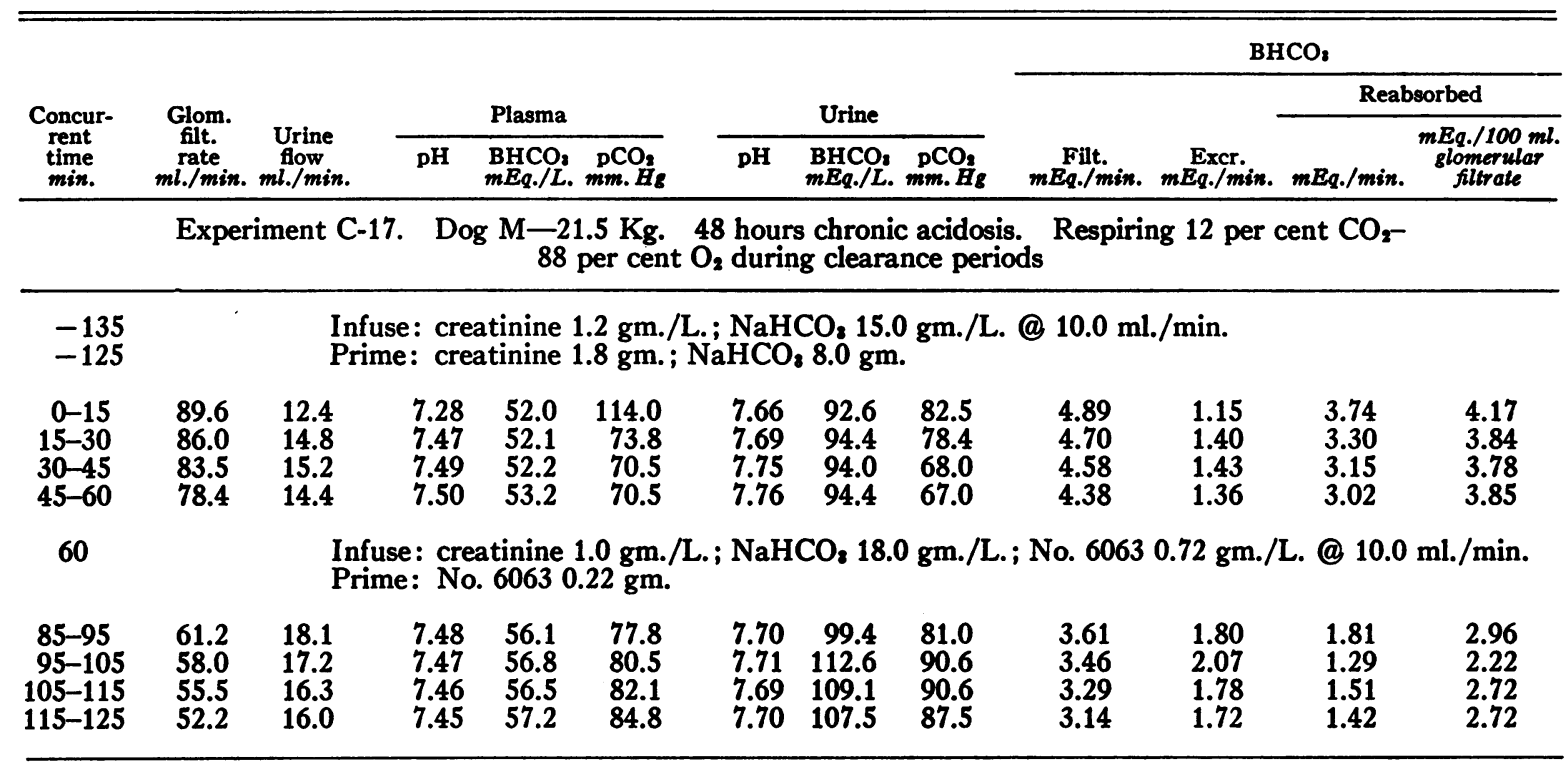

TABLE III

Bicarbonate reabsorption following cessation of chronic respiratory acidosis

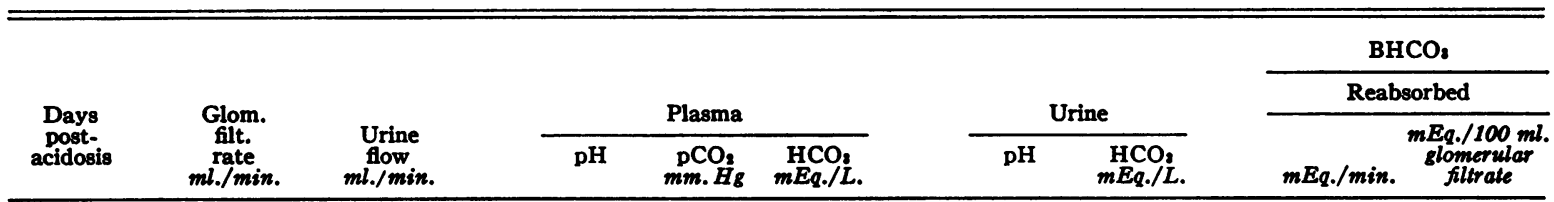

Experiment C-27. Dog S-15.0 Kg. Chronic respiratory acidosis-77 days

Prime: creatinine $0.8 \mathrm{gm}$.; $\mathrm{NaHCO}_{3} 7.0 \mathrm{gm}$.

Infuse: creatinine $0.9 \mathrm{gm}$./L.; $\mathrm{NaHCO}_{2} 10 \mathrm{gm} . / \mathrm{L}$. @ $10 \mathrm{ml} . / \mathrm{min}$.

Started approximately $45 \mathrm{~min}$. prior to each pair of clearance periods

\begin{tabular}{|c|c|c|c|c|c|c|c|c|c|}
\hline 0.25 & $\begin{array}{l}54.4 \\
44.9\end{array}$ & $\begin{array}{l}6.27 \\
5.46\end{array}$ & $\begin{array}{l}7.57 \\
7.60\end{array}$ & $\begin{array}{l}63 \\
56\end{array}$ & $\begin{array}{l}55.9 \\
55.5\end{array}$ & $\begin{array}{l}7.96 \\
7.89\end{array}$ & $\begin{array}{l}140 \\
138\end{array}$ & $\begin{array}{l}2.31 \\
1.87\end{array}$ & $\begin{array}{l}4.25 \\
4.16\end{array}$ \\
\hline 1 & $\begin{array}{l}60.5 \\
58.6\end{array}$ & $\begin{array}{l}6.57 \\
5.80\end{array}$ & $\begin{array}{l}7.57 \\
7.59\end{array}$ & $\begin{array}{l}73 \\
66\end{array}$ & $\begin{array}{l}64.2 \\
62.8\end{array}$ & $\begin{array}{l}7.89 \\
7.91\end{array}$ & $\begin{array}{l}153 \\
167\end{array}$ & $\begin{array}{l}3.08 \\
2.89\end{array}$ & $\begin{array}{l}5.10 \\
4.93\end{array}$ \\
\hline 3 & $\begin{array}{l}49.3 \\
52.8\end{array}$ & $\begin{array}{l}4.33 \\
4.53\end{array}$ & $\begin{array}{l}7.72 \\
7.74\end{array}$ & $\begin{array}{l}40 \\
40\end{array}$ & $\begin{array}{l}51.6 \\
50.2\end{array}$ & $\begin{array}{l}7.91 \\
8.01\end{array}$ & $\begin{array}{l}145 \\
163\end{array}$ & $\begin{array}{l}1.96 \\
1.96\end{array}$ & $\begin{array}{l}3.98 \\
3.72\end{array}$ \\
\hline 4 & $\begin{array}{l}52.0 \\
37.4\end{array}$ & $\begin{array}{l}7.22 \\
5.75\end{array}$ & $\begin{array}{l}7.64 \\
7.68\end{array}$ & $\begin{array}{l}56 \\
50\end{array}$ & $\begin{array}{l}58.5 \\
57.9\end{array}$ & $\begin{array}{l}7.88 \\
7.90\end{array}$ & $\begin{array}{l}130 \\
143\end{array}$ & $\begin{array}{l}2.16 \\
1.39\end{array}$ & $\begin{array}{l}4.16 \\
3.72\end{array}$ \\
\hline 7 & $\begin{array}{l}45.7 \\
46.1\end{array}$ & $\begin{array}{l}6.00 \\
7.00\end{array}$ & $\begin{array}{l}7.67 \\
7.70\end{array}$ & $\begin{array}{l}50 \\
43\end{array}$ & $\begin{array}{l}\mathbf{5 5 . 4} \\
\mathbf{5 3 . 5}\end{array}$ & $\begin{array}{l}7.87 \\
8.06\end{array}$ & $\begin{array}{l}128 \\
114\end{array}$ & $\begin{array}{l}1.71 \\
1.72\end{array}$ & $\begin{array}{l}3.74 \\
3.73\end{array}$ \\
\hline 11 & $\begin{array}{l}36.8 \\
34.8\end{array}$ & $\begin{array}{l}3.22 \\
2.90\end{array}$ & $\begin{array}{l}7.65 \\
7.67\end{array}$ & $\begin{array}{l}50 \\
46\end{array}$ & $\begin{array}{l}52.5 \\
52.1\end{array}$ & $\begin{array}{l}7.96 \\
7.95\end{array}$ & $\begin{array}{l}155 \\
164\end{array}$ & $\begin{array}{l}1.53 \\
1.43\end{array}$ & $\begin{array}{l}4.16 \\
4.10\end{array}$ \\
\hline 14 & $\begin{array}{l}43.3 \\
40.6\end{array}$ & $\begin{array}{l}5.97 \\
7.47\end{array}$ & $\begin{array}{l}7.54 \\
7.58\end{array}$ & $\begin{array}{l}\mathbf{5 3} \\
\mathbf{5 0}\end{array}$ & $\begin{array}{l}45.0 \\
44.9\end{array}$ & $\begin{array}{l}7.74 \\
7.80\end{array}$ & $\begin{array}{l}92 \\
91\end{array}$ & $\begin{array}{l}1.49 \\
1.23\end{array}$ & $\begin{array}{l}3.44 \\
3.03\end{array}$ \\
\hline
\end{tabular}


been demonstrated for conditions of normal $\mathrm{pCO}_{2}$ (6) and for acute respiratory acidosis (3).

The effect of No. $6063^{5}$ on the renal reabsorption of bicarbonate in chronic respiratory acidosis is illustrated by the data presented in Table II. During the first four periods of this experiment, obtained following 48 hours of chronic respiratory acidosis, elevated plasma bicarbonate concentration with frank excretion was obtained by infusing sodium bicarbonate. During these periods, the usual enhancement of bicarbonate reabsorption associated with chronic respiratory acidosis was attained. Between periods four and five a priming dose of No. 6063 (10 mg. per Kg.) was given, followed by a sustaining infusion containing No. 6063 (20 mg. per $\mathrm{Kg}$. per hr.). This resulted in a reduction in reabsorption of bicarbonate to values well below the control periods, but still increased with respect to values observed in the normal, non-acidotic state, or to values observed following No. 6063 in equal dosage during acute respiratory acidosis. Similar results were obtained in three other experiments. This suggests that the renal tubular adaptation which occurs in chronic respiratory acidosis is not specifically abolished by the enzyme inhibitor, rather that the drug exerts its usual action in blocking some fraction of enzymatically catalyzed reabsorption.

Studies were carried out in two dogs to determine the behavior of the renal mechanism for bicarbonate reabsorption during the period of recovery from chronic respiratory acidosis. Data obtained on one of these dogs in chronic respiratory acidosis for 77 days are presented in Table III. It will be noted that renal reabsorption of bicarbonate was elevated for 14 days following cessation of acidosis. Unfortunately, the dog died through an accident at this point. In another dog, in chronic respiratory acidosis for 21 days, bicarbonate reabsorption was still above normal on the sixth day, although in one period on the second day it approached normal.

Two factors complicate the interpretation of these results. First, the arterial $\mathrm{PCO}_{2}$ in these experiments was somewhat elevated, generally falling in the range of 50 to $60 \mathrm{~mm}$. Hg. This elevation occured despite minimal dosage of barbiturate,

\footnotetext{
$5 \mathrm{We}$ are indebted to the American Cyanamid Corporation for a supply of No. 6063 .
}

and may be a consequence of an altered sensitivity of the respiratory center to $\mathrm{CO}_{2}$. However, from a comparison of these data with data previously obtained on bicarbonate reabsorption in this range of $\mathrm{pCO}_{2}(3,4)$, it appears unlikely that the enhanced reabsorption observed here is solely attributable to the elevation in $\mathrm{pCO}_{2}$.

The second factor to be considered in interpreting these results is the moderate hypokalemia (1.7 to $3.5 \mathrm{mEq}$. per L.) usually associated with the enhancement in bicarbonate reabsorption. Since the dogs ate a normal diet and therefore presumably had a normal potassium intake, this implies either enhanced potassium excretion or an alteration in transcellular distribution of potassium. Whether the hypokalemia reflects a net depletion of body potassium stores, as is generally the case (7-9), and whether it is causally related to the enhanced bicarbonate reabsorption, cannot be determined from these data. In any event, the renal mechanism for bicarbonate reabsorption continues to function at a supranormal level for some time after the initiating stimulus-the inhalation of $\mathrm{CO}_{2}$-has been removed.

\section{DISCUSSION}

The data presented above indicate that chronic respiratory acidosis results in an enhancement of renal tubular reabsorption of bicarbonate bound base to rates significantly greater than those attained in response to acute respiratory acidosis. This adaptation appears to proceed most rapidly during the first 24 to 48 hours of respiratory acidosis, and less rapidly thereafter. Some hormonal mechanism, possibly involving the adrenal cortex, may be involved. The acute administration of cortisone to dogs with normal plasma $\mathrm{pCO}_{2}$ did not result in a significant enhancement of bicarbonate reabsorption (10). This does not, however, preclude the possibility that adrenal steroids, acting for prolonged periods in chronic respiratory acidosis, might act to enhance renal tubular reabsorption of bicarbonate. Preliminary results obtained by Giebisch (11) suggest that acute respiratory acidosis in dogs pretreated with moderately large doses of desoxycorticosterone acetate and cortisone, together with a high dietary salt intake, results in enhancement of bicarbonate 


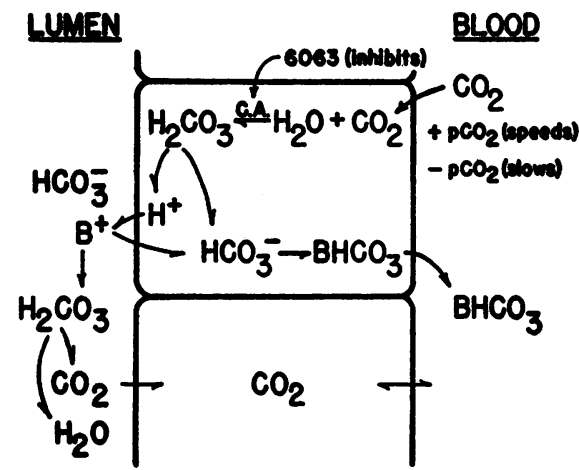

Fig. 3. Proposed Schema for Reabsorption of Bicarbonate

reabsorption to values within the range of those observed by us in chronic respiratory acidosis.

The schema outlined in Figure 3 has recently been proposed $(3,4)$ to explain the renal tubular reabsorption of bicarbonate bound base by an ion exchange mechanism. The intracellular hydration of $\mathrm{CO}_{2}$, enzymatically accelerated by carbonic anhydrase, yields carbonic acid. The dissociation of this acid produces hydrogen ions which are then exchanged across the cell membrane for ions of base bound by bicarbonate ions in the tubular urine. The carbonic acid thus formed in the tubular lumen dehydrates in part yielding molecular $\mathrm{CO}_{2}$ which may then diffuse back across the cell membrane and re-ënter the reabsorptive cycle, as pointed out by Brazeau and Gilman (4). The ions of base are returned to the peritubular blood accompanied by bicarbonate ions formed through the dissociation of carbonic acid within the cell.

Since the renal reabsorption of bicarbonate in acute respiratory acidosis has been found to be a function of the $\mathrm{pCO}_{2}$ of the body fluids, it has been proposed that an elevation in the $\mathrm{pCO}_{2}$ within the tubular cells, by a mass action effect, accelerates the hydration reaction and consequently enhances bicarbonate reabsorption.

From an inspection of the data it is apparent that, for a given $\mathrm{pCO}_{2}$, bicarbonate reabsorption in chronic respiratory acidosis is significantly greater than it is in acute respiratory acidosis. In the range of arterial $\mathrm{pCO}_{2}$ of 70 to $110 \mathrm{~mm}$. $\mathrm{Hg}$, the mean of many determinations of bicarbonate reabsorption in chronic respiratory acidosis was $4.14 \mathrm{mEq}$. per $100 \mathrm{ml}$. filtrate; whereas the mean of determinations in acute respiratory acidosis, similarly distributed over the same range, was $3.43 \mathrm{mEq}$. per $100 \mathrm{ml}$. filtrate.

We have noted above that in chronic respiratory acidosis there is increase in the splay of the curve relating reabsorption of bicarbonate to plasma bicarbonate concentration. This may indicate an alteration in the kinetics of the ion-exchange mechanism such that the reaction whose velocity determines the over-all rate of hydrogen ion transport is different from the rate-limiting reaction in conditions of normal or acutely elevated $\mathrm{CO}_{2}$ tension $(12,13)$. One alternative explanation would be that there is a greater dispersion of glomerular activity in chronic respiratory acidosis.

Table IV summarizes data relating bicarbonate reabsorption to plasma potassium concentration in a variety of experimental conditions. It is apparent that prior to bicarbonate infusion, no correlation exists between bicarbonate reabsorption and plasma potassium concentration. Furthermore, no correlation is evident during infusion of bicarbonate, although plasma potassium always decreased as a result of such infusion. Obviously differences in bicarbonate reabsorption between animals in acute and chronic respiratory acidosis cannot be related to changes in plasma potassium concentration.

Berliner, Kennedy, and Orloff (14) have postulated that potassium and hydrogen ions compete in the renal tubular cell for some common secretory mechanism. One might therefore anticipate that

TABLE IV

Renal bicarbonate reabsorption and plasma potassium concentration in various experimental conditions

\begin{tabular}{|c|c|c|c|}
\hline & & $\begin{array}{c}\text { Mean } \\
\text { BHCO } \\
\text { reabeorption } \\
m E q . / 100 \text { ml. } \\
\text { filtrate }\end{array}$ & $\begin{array}{l}\text { Plasma } \\
\text { potasaium } \\
\text { Mean } \\
\pm 2 \times S . D . \\
\text { mEq./L. }\end{array}$ \\
\hline \multirow{3}{*}{$\begin{array}{c}\text { No } \\
\text { bicarbonate } \\
\text { infused }\end{array}$} & \multirow{3}{*}{$\begin{array}{l}\text { Normal pCO} \\
\text { Acute respiratory } \\
\text { acidosis } \\
\text { Chronic respiratory } \\
\text { acidosis }\end{array}$} & 2.24 & $3.76 \pm 0.88$ \\
\hline & & 2.90 & $3.75 \pm 0.04$ \\
\hline & & 3.47 & $3.62 \pm 0.74$ \\
\hline \multirow{3}{*}{$\begin{array}{l}\text { Bicarbonate } \\
\text { infused }\end{array}$} & \multirow{3}{*}{$\begin{array}{l}\text { Normal pCO, } \\
\text { Acute respiratory } \\
\text { acidosis } \\
\text { Chronic respiratory } \\
\text { acidosis }\end{array}$} & 2.58 & $2.78 \pm 0.90$ \\
\hline & & 3.47 & $2.90 \pm 0.42$ \\
\hline & & 4.61 & $2.68 \pm 0.88$ \\
\hline
\end{tabular}


the intracellular concentration of potassium rather than the plasma concentration would be the factor determining bicarbonate reabsorption, if indeed potassium is to be accorded any significance. If cellular potassium were low, the concomitant increase in rate of secretion of hydrogen ions would account for a part of the enhanced reabsorption of bicarbonate bound base. On the other hand, a normal or increased cellular potassium concentration would lend support to the concept that the adaptation to chronic respiratory acidosis involves an enhancement of the mechanism for secreting hydrogen ions.

We have no data on potassium concentration in renal tubular cells. Muscle potassium in rats in chronic respiratory acidosis is in the high normal range (15). One might argue that, if renal tubular cells in the dog are similar, they are not depleted of potassium. However, no unequivocal statement is possible until data on potassium in renal tubular cells in chronic respiratory acidosis are available.

From a consideration of the reactions diagrammed in Figure 3, it may be concluded that there are at least two processes in the reabsorptive mechanism, acceleration of which could result in an enhanced bicarbonate reabsorption. The first of these processes is the hydration of $\mathrm{CO}_{2}$ within the cell to produce carbonic acid. For a given $\mathrm{pCO}_{2}$, acceleration of this reaction would require an increase in the activity of renal carbonic anhydrase. The other process, the kinetics of which might be affected by this adaptation, consists of those energy-requiring reactions involved in the transport of hydrogen ions across the cell membrane. The nature of this process is not known at present.

From our data, it is not possible to specify which of the reaction velocities has been altered during the adaptation to chronic respiratory acidosis, or whether a change in more than one is involved. Calculations based on available data concerning the carbonic anhydrase activity present in normal kidneys (16) are subject to a large degree of uncertainty. However, these calculations suggest that the amount of carbonic anhydrase normally present suffices to account for the most rapid rates of bicarbonate reabsorption observed in our studies. It is therefore suggested that the adaptation to chronic respiratory acidosis probably involves the mechanism for the transport of hydrogen ions.

The available data concerning possible changes in renal enzyme activities in response to respiratory acidosis are conflicting. Killion and Schaefer (17) exposed rats and guinea pigs to atmospheres containing 30 per cent $\mathrm{CO}_{2}$, and reported significant increases in renal carbonic anhydrase activity occurring within one hour. However, Seldin (18) in preliminary studies on rats in an atmosphere containing 10 per cent $\mathrm{CO}_{2}$ for periods of two weeks, was unable to demonstrate any significant increase in renal carbonic anhydrase activity. A more precise description of the nature of the renal enzymatic adaptation to chronic respiratory acidosis awaits further study.

\section{SUMMARY AND CONCLUSIONS}

1. The renal reabsorption of bicarbonate bound base in chronic respiratory acidosis is enhanced to values significantly greater than those observed either under conditions of normal $\mathrm{pCO}_{2}$ or in acute respiratory acidosis.

2. The enhancement of bicarbonate reabsorption varies as a direct function of the duration of acidosis, rising most rapidly during the first 24 to 48 hours. This may occur as the result of a hormonal adaptation, possibly involving the adrenal cortex.

3. These results have been discussed in terms of a schema originally proposed on the basis of results obtained in acute respiratory acidosis. Since, for a given $\mathrm{pCO}_{2}$, bicarbonate reabsorption in chronic respiratory acidosis is significantly greater than in acute respiratory acidosis, some adaptation involving the kinetics of the reactions concerned is implied. It is suggested that this probably involves the mechanism for the secretion of hydrogen ions.

\section{REFERENCES}

1. Peters, J. P., and Van Slyke, D. D., Quantitative Clinical Chemistry, Interpretations. Vol. I. Baltimore, The Williams \& Wilkins Company, 1932.

2. Shock, N. W., and Hastings, A. B., Studies on the acid-base balance of the blood. IV. Characterization and -interpretation of displacement of the acid-base balance. J. Biol. Chem., 1936, 112, 239. 
3. Dorman, P. J., Sullivan, W. J., and Pitts, R. F., The renal response to acute respiratory acidosis. J. Clin. Invest., 1954, 33, 82.

4. Brazeau, P., and Gilman, A., Effect of plasma $\mathrm{CO}_{2}$ tension on renal tubular reabsorption of bicarbonate. Am. J. Physiol., 1953, 175, 33.

5. Relman, A. S., Etsten, B., and Schwartz, W. B., The regulation of renal bicarbonate reabsorption by plasma carbon dioxide tension. J. Clin. Invest., 1953, 32, 972.

6. Pitts, R. F., and Lotspeich, W. D., Bicarbonate and the renal regulation of acid base balance. Am. J. Physiol., 1946, 147, 138.

7. Darrow, D. C., Schwartz, R., Iannucci, J. F., and Coville, $F$., The relation of serum bicarbonate concentration to muscle composition. J. Clin. Invest., 1948, 27, 198.

8. Cooke, R. E., Segar, W. E., Cheek, D. B., Coville, F. E., and Darrow, D. C., The extrarenal correction of alkalosis associated with potassium deficiency. J. Clin. Invest., 1952, 31, 798.

9. Orloff, J., Kennedy, T. J., Jr., and Berliner, R. W., The effect of potassium in nephrectomized rats with hypokalemic alkalosis. J. Clin. Invest., 1953, 32, 538.
10. Roberts, K. E., Magida, M. G., and Pitts, R. F., Relationship between potassium and bicarbonate in blood and urine. Am. J. Physiol., 1953, 172, 47.

11. Giebisch, G. H., Personal communication.

12. Pitts, R. F., A renal reabsorptive mechanism in the dog common to glycin and creatine. Am. J. Physiol., 1943, 140, 156.

13. Shannon, J. A., Renal tubular excretion. Physiol. Rev., 1939, 19, 63.

14. Berliner, R. W., Kennedy, T. J., Jr., and Orloff, J., Factors affecting the transport of potassium and hydrogen ions by the renal tubules. Arch. internat. de pharmacodyn. et de thérap., 1954, 97, 299.

15. Cooke, R. E., Coughlin, F. R., Jr., and Segar, W. E., Muscle composition in respiratory acidosis. $\mathrm{J}$. Clin. Invest., 1952, 31, 1006.

16. Davenport, H. W., and Wilhelmi, A. E., Renal carbonic anhydrase. Proc. Soc. Exper. Biol. \& Med., 1941, 48, 53.

17. Killion, P. J., and Schaefer, K. E., Effects of exposure to $30 \% \mathrm{CO}_{2}$ in air and in $\mathrm{O}_{2}$ on carbonic anhydrase activity in blood and kidney. Federation Proc., 1954, 13, 78.

18. Seldin, D. W., Personal communication. 